\title{
Heavy Metal Content of Abattoir Waste and Municipal Sludge in Soil and Water along Jakara River in Kano, Kano State, Nigeria
}

\author{
Ahmad R. Sanda1, Idris Ahmad², Calvin Alvin Gaye ${ }^{3}$ \\ ${ }^{1}$ Department of Soil Science, Kebbi State University of Science and Technology, Aliero, Nigeria \\ ${ }^{2}$ Department of Agriculture, Ingawa Local Government Area, Katsina State, Nigeria \\ ${ }^{3}$ Department of Physics, University of Liberia, Monrovia, Liberia \\ Email: sandaahmad90@gmail.com
}

Received 12 July 2016; accepted 14 August 2016; published 17 August 2016

Copyright (C) 2016 by authors and OALib.

This work is licensed under the Creative Commons Attribution International License (CC BY). http://creativecommons.org/licenses/by/4.0/

(c) (i) Open Access

\begin{abstract}
Pollution of general environment has increasingly gathered a global interest in this respect; contamination of agricultural soils with heavy metals has always been considered a critical challenge in scientific community. Heavy metals are generally present in agricultural soils at low levels. Due to their cumulative behavior and toxicity, however, they have a potential hazardous effect not only on crop plants but also on human health. A study was carried out on the quality of Jakara River water in Kano which is the main source of water for municipal agriculture in the area to evaluate its suitability and otherwise for agricultural crop production. Heavy metals in both the soil and water were found to be low, but their value in soils is higher due to continuous accumulation and in the soil at $0-15 \mathrm{~cm}$ depth the concentration followed these trends: $\mathrm{Fe}>\mathrm{Cr}>\mathrm{Mn}>\mathrm{Ni}>$ both $\mathrm{Pb}$, $\mathrm{Cu}$ and $\mathrm{As}>\mathrm{Zn}$ while at $15-30 \mathrm{~cm}$ soil depth it was found that $\mathrm{Mn}>\mathrm{Ni}>\mathrm{Zn}>\mathrm{As}>\mathrm{Cr}>\mathrm{Pb}$ and $\mathrm{Fe}>$ Cu.
\end{abstract}

\section{Keywords}

Contamination, Abattoir Waste, Municipal Waste, Heavy Metal

Subject Areas: Soil Science

\section{Introduction}

Conceptually, water quality refers to the characteristics of a water supply that will influence its suitability for a specific use, i.e. how well the quality meets the needs of the user. Quality was defined by certain physical, chemical and biological characteristics. Even a person preference such as taste is a simple evaluation of acceptability. For example, if two drinking waters of equally good quality are available, people may express a prefe- 
rence for one supply rather than the other; the better testing water becomes the preferred supply. In irrigation water evaluation, emphasis is placed on the chemical and physical characteristics of the water and only rarely is any other factors considered important.

Specific use have different quality needs and water supply in one way is considered more acceptable if it produces better results or causes fewer problems than an alternative water supply; for example, good quality river water which can be sued successfully for irrigation may be unacceptable for municipal use without treatment to remove the sediment because of its sediment load. Similarly, snowmelt water of excellent quality for municipal use may be too corrosive for industrial use without treatment to reduce its corrosion potentials. The ideal situation is to have several supplies from which to make a selection, but normally only one supply is available. In this case, the quality of the available supply must be evaluated to see how it fits the intended use. Most of the experience in using water of different qualities has been gained from observations and detailed study of problems that developed following use.

Toxicity problems occur if certain constituents (ions) in the soil or water are taken up by the plant and accumulate to concentration high enough to cause crop damage or reduced yield. The degree of damage depends on the uptake and the crop sensitivity. The permanent, perennial type crops (tree crops) are the more sensitive. Damage often occurs at relatively low ion concentrations for sensitive crops. It is usually first evidenced by marginal leaf born and interveinal chlorosis plants, while in human there were reported cases of liver and kidney related problems. Toxicity can also occur from direct absorption of the toxic substances through leaves wet. As concentrations increase in the applied water damage develops more rapidly and becomes progressively more severe.

Pollution of general environment has increasingly gathered a global interest. In this respect, contamination of agricultural soils with heavy metals has always been considered a critical challenge in scientific community [1]. Heavy metals are generally present in agricultural soils at low levels. Due to their cumulative behavior and toxicity however, they have a potential hazardous effect not only on crop plants but also on human health [2].

With the increasing awareness of risk assessment of heavy metals in food crops, monitoring of these metals in agricultural soils is therefore critical as it gives information in nutritional planning and provides data for epidemiological studies [3]. Information about the movement of metals through ecosystem as well as their bioaccumulation, tropic transfer, and potential toxicological effects is provided by measure of the concentrations in soils and biota. The persistence, biomagnifications, and distribution of trace metals in terrestrial food webs have been investigated in may studies [4]-[7]; patterns of uptake and bioaccumulation have been studied by investigation of the relationship between metal concentration in soils and several parts of plant tissues [8]-[10].

Both abattoir waste water and municipal sledge waste has led to multi-elements concentration of soils [11]. Elevated concentration of certain trace elements, when mobile, can cause great environmental concern by accumulating and contaminating soils, vegetation, animals or surface and ground waters [12], health hazard and agricultural water contamination. The objective of this paper is therefore to help the reader to better understand the effect of water quality upon soils and crops to assist in selecting suitable alternatives to cope with potential water quality related problems that might reduce produce under prevailing conditions of use.

\section{Materials and Methods}

The study was carried out on the water and soils of Jakara River that cut across Kano Municipal and Sabon Gari Area of Kano. Soil depth, while the water sample was collected from the flowing water of the river some 1500 meters away from the abattoir so as to enable for a through mixing of the water from domestic areas and the abattoir sledge.

Nitric acid washed plastic bottles were used in collecting the water samples. The sample collected was preserved with $5 \mathrm{ml}$ conc. Nitric acid and transported to laboratory for analysis. Heavy metals were determined from the sample according to [13] and measured using atomic assumption spectrophotometer. The soil samples collected were directly taken to laboratory, air dried, crushed with pestle and mortar, sieved through $2 \mathrm{~mm}$ sieve and analysis started immediately thereafter 5 of soil sample were placed in $100 \mathrm{ml}$ beaker, $3 \mathrm{ml} 30 \%$ hydrogen peroxide was added following a procedure described by [14]. This was left to stand for 60 mins, until the vigorous reaction ceased. $75 \mathrm{ml}$ of $0.5 \mathrm{~m}$ solution of HCL was added and the content heated fatly at low heat on hot plate for about $2 \mathrm{hrs}$. The digest was then filtered into $50 \mathrm{ml}$ standard flask. Triplicate digestion of each sample was carried out. Then the quantitation of metallic content of digested samples was carried out with the flame 
atomic absorption spectrophotometer model AA650. The results were thus presented in the following section.

\section{Results and Discussion}

The levels of the heavy metals determined at the sampling points along Jakara River are presented in Table 1. From these results it was discovered that the concentrations of the heavy metal tested in soils at each depth was found to the higher than those in the water for irrigation. This is because of the fact that as a result of continues use of such water the metals were thus accumulated in the soil as a residual component of the water applied during irrigation. However, with the exception of Fe, all the metal tested was within the maximum allowable limit for irrigation water by [15]. The higher concentration of Fe in these water could probably due to the fact that some water from Dala Hill were it was historically believed that the ancient people in Kano were said to be using as the site for iron-ore mining, drain in to the city drainage system which finally drains in to the Jakara River. A significant differences were observed between the concentrations of these metals between the soil sampling depth, with $0-15 \mathrm{~cm}$ soil depth showing higher concentration which is believed to be due to the fact that 0 $-15 \mathrm{~cm}$ is the area for deposition for the water containing these metals. Zn has the lowest concentration of 0.04 mgll as compared to all other metals studied in which the following ranking was observed $\mathrm{Cr}>\mathrm{Mn}>\mathrm{Ni}>$ both $\mathrm{Pb}, \mathrm{Cu}$ and As. But the concentration in $15-30 \mathrm{~cm}$ soil depth shows the following ranking $\mathrm{Mn}>\mathrm{Ni}>\mathrm{Zn}>\mathrm{As}>$ $\mathrm{Cr}>\mathrm{Pb}$ and $\mathrm{Fe}$, while the lowest value of $0.1 \mathrm{mgll}$ was shown by $\mathrm{Cu}$.

The sources of the heavy metals with higher concentrations in the wastewater could probably be from the metals works, construction and engineering and domestic and abattoir waste. However, the concentration of these metals could increase with location that is at both upstream and downstream. In several other studies, low level of $\mathrm{Pb}, \mathrm{Mn}, \mathrm{Ni}, \mathrm{Cd}, \mathrm{Cr}$, and $\mathrm{Cu}$ upstream with the corresponding higher level at the downstream in many rivers has long been reported, and increasing discharge of contaminants with distance towards downstream has been blamed for this trend [16]. Jakara River at both upstream and downstream is been used to irrigation many vegetables and other food crops consumed in the city in crops receiving such contaminated water during irrigation is always common in most cities and metals could be biomagnified along food chain to a higher tropic level [17] [18]. Consumption of such food crops could expose man and animals to untold heavy metals hazards. Wet and dry fallout of atmospheric particulate matter arrived from natural sources as well as man activities can introduce large quantities of metals into the open flowing river. In additions to the natural sources, the discharge of various treated and untreated liquid wastes to the water body can introduce large amounts of trace metals to rivers and lakes [19].

\section{Conclusion}

Metals are notable for their wide environmental dispersion from such activity, their tendency to accumulate in selected tissues of the human body, and their overall potential to be toxic even at relatively minor levels of ex-

Table 1. Mean concentration of various metals (mg/I) across different sampling sites along Jakara River Kano.

\begin{tabular}{ccccc}
\hline \multirow{2}{*}{ Heavy metals } & $\begin{array}{c}\text { Maximum allowable } \\
\text { in irrigation water }\end{array}$ & $\begin{array}{c}\text { Values for water at } \\
\text { sampling site }(\mathrm{mg} / \mathrm{I})\end{array}$ & \multicolumn{2}{c}{ Values for soil at various depth } \\
\cline { 4 - 4 } $\mathrm{Pb}$ & - & 0.05 & $0-15 \mathrm{~cm}$ & $15-30 \mathrm{~cm}$ \\
$\mathrm{Cu}$ & 0.2 & 0.05 & 0.8 & 0.3 \\
$\mathrm{Zn}$ & Up to 5.0 & 0.04 & 0.1 & 1.0 \\
$\mathrm{Mn}$ & 0.2 & 0.08 & 1.8 & 1.7 \\
$\mathrm{Ni}$ & 0.2 & 0.07 & 2.4 & 0.1 \\
$\mathrm{As}$ & 0.1 & 0.05 & 1.1 & 0.8 \\
$\mathrm{Cr}$ & 0.1 & 0.09 & 1.0 & 0.5 \\
$\mathrm{Fe}$ & 0.01 & 0.2 & 0.8 & 0.6 \\
\hline
\end{tabular}


posure. Some metals, such as copper and iron, are essential to life and play irreplaceable roles in, for example, the functioning of critical enzyme systems. Other metals are xenobiotics; i.e., they have no useful role in human physiology (and most other living organisms) and, even worse, as in the case of lead and mercury, may be toxic even at trace levels of exposure. Even those metals that are essential, however, have the potential to turn harmful at very high levels of exposure, a reflection of a very basic tenet of toxicology- "the dose makes the poison". One reflection of the importance of metals relative to other potential hazards is their ranking by the U.S. Agency for Toxic Substances and Disease Registry (ATSDR), which lists all hazards present in toxic waste sites according to their prevalence and the severity of their toxicity. The first, second, third, and sixth hazards on the list are heavy metals: lead, mercury, arsenic, and cadmium, respectively. Exposure to metals can occur through a variety of routes. Metals may be inhaled as dust or fume (tiny particulate matter, such as the lead oxide particles produced by the combustion of leaded gasoline). Metals may also be ingested involuntarily through food and drink. The amount that is actually absorbed from the digestive tract can vary widely, depending on the chemical form of the metal and the age and nutritional status of the individual. Once a metal is absorbed, it distributes in tissues and organs. Excretion typically occurs primarily through the kidneys and digestive tract, but metals tend to persist in some storage sites, like the liver, bones, and kidneys, for years or decades. However, the heavy metals content of the water and soil of Jakara river bank is getting higher due to discharge of various treated and untreated liquid and other soluble solid substances to this water body. Despite the toxicity of these metals to humans and animals, government at various levels were reluctant to provide other alternatives of water source for farmers so as to stop using this water in order to safe-guard the health of their citizens. Hence, this deadly urban agricultural practice should be discouraged as the state has been blessed with over 27 dams which contain virtually safer water for agricultural production.

\section{References}

[1] Faruk, O., Nazim, S. and Metin Kara, S. (2006) Monitoring of Cadmium and Micronutrients in Spices Commonly Consumed in Turkey. Research Journal of Agriculture and Biological Sciences, 2, 223-226.

[2] Das, P., Samanatary, S. and Rout, G.R. (1997) Studies on Cadmium Toxicity in Plants: A Review. Environmental Pollution, 96, 29-36. http://dx.doi.org/10.1016/S0269-7491(97)00110-3

[3] Bruce, A. and Bergstrom, L. (1983) Use Requirement for Data Bases and Applications in Research. Food and Nutrition Bulletin, 5, 24-29.

[4] Scharenberg, W. and Evelin, E. (1996) Distribution of Heavy Metals in Woodland Food Web. Bulletin of Environmental Contamination and Toxicology, 56, 389-396. http://dx.doi.org/10.1007/s001289900056

[5] Seifert, M., Anke, S., Hozinger, S., Janitz, M., Arahold, W. and Anke, M. (1999) Cadmium and Strontium Content of Mice, Shrews and Some Invertebrates. Journal of Trace and Microprobe Techniques, 17, 357-365.

[6] Milton, A. and Johnson, M. (2002) Food Chain Transfer of Zinc within the Ecosystems of Old and Modern Metalliferous Mine Western (200^). Environmental Technology, 23, 525-536. http://dx.doi.org/10.1080/09593332308618393

[7] Blakern, A.A. (2003) Accumulation and Migration of Trace Elements along Tropic Chains in Ecosystems of the Chaktal Biosphere Reserved (The Western Tien Shan, Uzbekistan). Russian Journal of Ecology, 34, 68-71. http://dx.doi.org/10.1023/A:1021827408038

[8] Kalas, J., Steinnes, E. and Lierhagen, S. (2000) Lead Exposure of Small Herbivorous Vertebrates from Atmospheric Pollution. Environmental Pollution, 85, 21-29. http://dx.doi.org/10.1016/S0269-7491(99)00155-4

[9] Martens, J., Luyssaet, S., Verbeeren, S., Vervaeke, P. and Lust, N. (2001) Cd and Zn Concentration in Small Mammals and Willow Leaves on Disposal Facilities for Dredge Materials. Environmental Pollution, 115, 17-22. http://dx.doi.org/10.1016/S0269-7491(01)00096-3

[10] Nan, Z., Li, J., Zhang, J. and Cheng, G. (2002) Cadmium and Zinc Interaction and Their Transfer in Soil-Crop System under Actual Filed Conditions. The Science of the Total Environment, 285, 187-195. http://dx.doi.org/10.1016/S0048-9697(01)00919-6

[11] Alloway, B.J. (1995) Heavy Metals in Soils. Blackie Academy and Profession, London. http://dx.doi.org/10.1007/978-94-011-1344-1

[12] Rose, S.M. (1994) Toxic Metals in Soil-Plant Systems. University of Bristol, Bristol.

[13] U.S. EPA (1994) Drinking Water Standards and Health Advisories Table. U.S. EPA, San Francisco, California.

[14] Shariada, M. (1990) Heavy Metals in Mangrove Sediments of the United Arab Emirates Shoreline (Arabian Gulf). Water, Air, \& Soil Pollution, 116, 523-534. http://dx.doi.org/10.1023/A:1005139020681 
[15] FEPA (1991) National Interim Guidelines and Standards for Industrial Effluents, Gaseous Emission and Hazardous Waste Management in Nigeria. Federal Environmental Protection Agency, Lagos.

[16] Gasparon, M. and Burges, J.S. (2000) Human Impacts in Antarctica, Trace Element Geochemistry of Fresh Water Lakes in the Larsemann Hill, East Antarctica. Environmental Geology, 39, 396-976. http://dx.doi.org/10.1007/s002549900010

[17] Turkdogan, M.K., Kilicel, F., Kara, K., Tuncer, I. and Uygan, I. (2003) Heavy Metals in Soils, Vegetables and Fruits in the Endemic Upper Gastrointestinal Cancer Region of Turkey. Environmental Toxicology and Pharmacology, 13, 175179. http://dx.doi.org/10.1016/S1382-6689(02)00156-4

[18] Wang, Q.R., Cui, Y.S., Liu, X.M., Dong, Y.T. and Christie, P. (2003) Soil Contamination and Plant Uptake of Heavy Metals at Polluted Sites in China. Journal of Environmental Science and Health, Part A-Toxic/Hazardous Substances \& Environmental Engineering, 38, 823-828. http://dx.doi.org/10.1081/ESE-120018594

[19] Pires, A.M.M. and Mattiazzo, M.E. (2003) Bio-Solids Conditioning and the Availability of Cu and Zn for Rice. Scientia Agricola, 60, 161-166. http://dx.doi.org/10.1590/S0103-90162003000100024

\section{Submit or recommend next manuscript to OALib Journal and we will provide best service for you:}

- Publication frequency: Monthly

- 9 subject areas of science, technology and medicine

- Fair and rigorous peer-review system

- Fast publication process

- Article promotion in various social networking sites (LinkedIn, Facebook, Twitter, etc.)

- Maximum dissemination of your research work

Submit Your Paper Online: Click Here to Submit

Contact Us: service@oalib.com 